Published in final edited form as:

Semin Oncol. 2014 August ; 41(4): 496-510. doi:10.1053/j.seminoncol.2014.06.004.

\title{
Antibody-based immunotherapy for malignant glioma
}

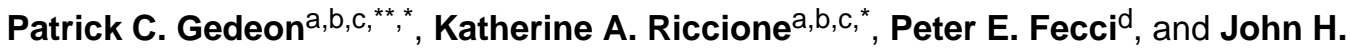 \\ Sampson ${ }^{a, b, c}$
}

aDuke Brain Tumor Immunotherapy Program, Division of Neurosurgery, Department of Surgery, Duke University Medical Center, Durham, NC 27710

bDepartment of Biomedical Engineering, Duke University, Durham, NC 27708

'The Preston Robert Tisch Brain Tumor Center at Duke, Duke University Medical Center, Durham, NC 27710

dDepartment of Neurosurgery, Massachusetts General Hospital, Harvard Medical School, Boston, MA 02114

\begin{abstract}
Conventional therapy for malignant glioma (MG) fails to specifically eliminate tumor cells, resulting in toxicity that limits therapeutic efficacy. In contrast, antibody-based immunotherapy utilizes the immune system to eliminate tumor cells with exquisite specificity. Increased understanding of the pathobiology of MG and the profound immunosuppression present among patients with MG has revealed several biologic targets amenable to antibody-based immunotherapy. Novel antibody engineering techniques allow for the production of fully human antibodies or antibody fragments with vastly reduced antigen-binding dissociation constants, increasing safety when used clinically as therapeutics. In this report, we summarize the use of antibody-based immunotherapy for MG. Approaches currently under investigation include the use of antibodies or antibody fragments to: 1) redirect immune effector cells to target tumor mutations, 2) inhibit immunosuppressive signals and thereby stimulate an immunological response against tumor cells, and 3) provide co-stimulatory signals to evoke immunologic targeting of tumor cells. These approaches demonstrate highly compelling safety and efficacy for the treatment of MG, providing a viable adjunct to current standard-of-care therapy for MG.
\end{abstract}

\section{Keywords}

antigens; antibodies; cancer; central nervous system; immunotherapy

(C) 2014 Elsevier Inc. All rights reserved.

** Author for correspondence. Tel.: 919-684-6384, Fax: 919-684-9045, patrick.gedeon@ duke.edu, Duke University Medical Center, Box 3050, Durham, NC 27710, USA.

These authors contributed equally to this work

Publisher's Disclaimer: This is a PDF file of an unedited manuscript that has been accepted for publication. As a service to our customers we are providing this early version of the manuscript. The manuscript will undergo copyediting, typesetting, and review of the resulting proof before it is published in its final citable form. Please note that during the production process errors may be discovered which could affect the content, and all legal disclaimers that apply to the journal pertain. 


\section{Malignant primary brain tumors and immunotherapy}

Malignant primary brain tumors are the most frequent cause of cancer death in children, ${ }^{1}$ are more common than Hodgkin lymphoma, ovarian and testicular cancer and are responsible for more deaths than malignant melanoma. ${ }^{2}$ Despite aggressive, image-guided tumor resection; ${ }^{3}$ high-dose external beam radiotherapy ${ }^{4}$ or brachytherapy; ${ }^{5}$ optimized chemotherapy ${ }^{6}$ and recent advances in anti-angiogenic treatments, ${ }^{7}$ patients with glioblastoma (GBM) live less than an average of 15 months from the time of diagnosis. 6 , 8 Standard-of-care therapies for malignant gliomas (MGs) fail to eliminate tumor cells specifically and as a result are limited by incapacitating damage to surrounding normal brain and systemic tissues. ${ }^{9}$ In contrast, by virtue of exploiting the inherit specificity of the immune system, anti-cancer immunotherapy provides a promising, highly tumor-specific platform for safe and effective therapy. Pivotal approvals by the United States Food and Drug Administration (FDA) for the immune-based cancer therapies sipuleucel-T and ipilimumab, which demonstrate significant survival benefits in patients with hormonerefractory prostate cancer and metastatic melanoma, respectively, ${ }^{10,11}$ have further validated immunotherapy as a viable treatment modality for cancer.

\section{Antibodies as an immunotherapeutic modality for intracerebral malignancy}

The exquisite epitope-binding-specificity imparted by monoclonal antibodies (mAbs) provides an ideal platform for precisely targeted immunotherapy. Intrinsic, high-affinity antigen recognition can further be enhanced with affinity maturation techniques, such as in vitro directed evolution; this technique has produced antibody-derived single-chain variable fragments (scFvs) with dissociation kinetics slower than the tightly bound streptavidinbiotin complex. ${ }^{12}$ Further advances have also allowed for the production of fully human mAbs via phage display technology, transgenic mouse platforms and, more recently, mRNA and ribosome display, ${ }^{13}, 14$ drastically reducing the risk of immunogenicity against the drug and increasing clinical safety. Complications associated with murine antibodies previously used in the clinic, including cytokine release syndrome ${ }^{15,16}$ and human anti-mouse antibody (HAMA) formation leading to rapid clearance from patients' serum ${ }^{17}$; unpredictable doseresponse relationships ${ }^{16,18}$ and an acute, potentially severe influenza-like syndrome $16,18,19,20$, can be entirely averted.

While antibodies are present in the central nervous system (CNS) in physiologic states, ${ }^{21}$ glioma-induced changes render lesions particularly susceptible to antibody-based immunotherapy. Glioma tumor cells induce compositional changes in the basal lamina and astrocytic components of the neurovascular unit (NVU), disrupting the integrity of the blood-brain barrier (BBB). In addition to increasing tumor burden and heightening tumor invasion of the surrounding parenchyma, ${ }^{22}$ this allows for enhanced penetrance of large soluble molecules, such as antibodies, from the vascular compartment. For the treatment of GBM, several studies have demonstrated that intravenously (IV) administered antibodies gain access to intracranial (IC) tumors and exert significant therapeutic benefit. ${ }^{23,24,25,26} \mathrm{In}$ murine GBM models, the antitenascin antibody (81C6) directed against a component of the tumor stroma showed significant localization and therapeutic activity following systemic administration, ${ }^{23,24}$ and in clinical trials, IV administration of radiolabeled 81C6 showed 
selective tumor localization. ${ }^{26}$ The antibody also accumulated in other tissues expressing high levels of tenascin, including the spleen, bone marrow and liver. As a further example, clinical evaluation of an antibody directed against the entirely tumor-specific mutation of the epidermal growth factor receptor (EGFRvIII), demonstrated higher levels of brain-tumorspecific uptake following IV administration, ${ }^{25}$ suggesting that in the absence of cross reactivity with peripherally located epitopes, such as that seen with tenascin, an antibody sink created by the exclusive expression of the target epitope within the CNS may result in enhanced antibody localization to the CNS.

\section{Tumor-specific targets and EGFRvIII}

The vast majority of proteins found on the surface of tumor cells are also expressed on normal healthy tissue. While overexpression of specific surface antigens is characteristic of various tumors, most often these antigens are tumor-associated antigens also expressed on the surface of healthy cells. Targeting such tumor-associated antigens via immunotherapeutic methods holds great risk for autoimmunity and thereby undermines the specificity imparted by immunotherapeutic approaches. Tumor-specific antigens, however, occur as a result of mutations in somatic genes and, when targeted therapeutically, are far less likely to be associated with autoimmunity. Most tumor-specific antigens occur randomly due to the genetic instability inherent to human cancers ${ }^{27}$ and as a consequence are patient specific.

EGFRvIII, however, is a frequent and consistent tumor-specific mutation seen in

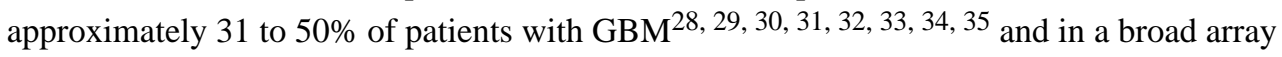
of other cancers. ${ }^{33}$, 36, 37, 38, 39, 40, 41 Among patients with EGFRvIII-positive GBM, 37 to $86 \%$ of tumor cells express the mutated receptor, ${ }^{34}$ indicating that the mutation is translated with significant consistency. The mutation consists of an in-frame deletion of 801 base pairs in the extracellular portion of the wild-type receptor, generating a novel glycine residue at the fusion junction. ${ }^{42,} 43$ This produces a highly immunogenic, cell-surface, tumor-specific epitope. ${ }^{44}$ Importantly, antibodies directed against EGFRvIII are entirely tumor-specific and do not cross react with the wild-type receptor located on untransformed, healthy cells. ${ }^{44}$

The mutated receptor plays a significant role in tumor pathobiology. EGFRvIII encodes for a constitutively active tyrosine kinase receptor ${ }^{45,46}$ that enhances tumor cell growth ${ }^{45,47,48}$ and invasion 49,50 while conferring radiation ${ }^{51}$ and chemotherapeutic ${ }^{52,53}$ resistance.

Among patients with GBM, expression of EGFRvIII is an independent, negative prognostic indicator. ${ }^{54}$ EGFRvIII also enhances the growth of neighboring EGFRvIII-negative tumor cells via cytokine-mediated paracrine signaling ${ }^{55}$ and by transferring a functionally active oncogenic receptor to EGFRvIII-negative cells through the release of lipid-raft related microvesicles. ${ }^{56}$ Recent research has also found that EGFRvIII is expressed in glioma stem cells (GSC), ${ }^{57,58}$ an important consideration given the paradigm that tumor stem cells (TSCs) represent a subpopulation of cells that give rise to all differentiated tumor cells. ${ }^{59}$ Altogether, the specificity, high frequency of surface expression and oncogenicity of the EGFRvIII mutation make it an ideal target for antibody-based immunotherapy. 


\section{Bispecific antibody redirected immunotherapy}

MG lesions are characteristically heavily infiltrated with $\mathrm{T}$ cells, ${ }^{60,61}$ and substantial evidence suggests that, if appropriately redirected, $\mathrm{T}$ cells, and in particular, cytotoxic $\mathrm{T}$ lymphocytes (CTLs), have the ability to eradicate large, well-established tumors. ${ }^{62}$ Although functionally effective, many $\mathrm{T}$ cell based therapies have prohibitive limitations. $\mathrm{T}$ cells genetically engineered to target tumor antigens, for example, are effective, but limited due to the fact that they rely on heavily-trained laboratory personnel to produce individual, patient-specific vaccines. Furthermore, they require viral transduction, there is a lack knowledge regarding the ideal T-cell phenotype needed, and are difficult to control once infused. Alternatively, activating $\mathrm{T}$ cells in vivo by single arm agonistic mAbs poses the risk of autoimmunity as a result of global ligation of circulating T cells throughout the body. ${ }^{63} \mathrm{In}$ direct contrast, bispecific antibody constructs are highly safe and effective by virtue of being able to activate $\mathrm{T}$ cells only in proximity to tumor cells expressing a target antigen. Due to their relative ease of manufacture, highly-specific nature and localized mode-of-action, bispecific antibodies overcome many of the limitations associated with the alternative T-cell based therapies described above.

Bispecific antibodies termed bispecific $\mathrm{T}$ cell engagers (BiTEs) are monomeric proteins consisting of two antibody-derived, scFvs translated in tandem. ${ }^{64}$ These constructs possess one effector-binding arm specific for the epsilon subunit of T-cell CD3 and an opposing target-binding arm directed against an antigen that is expressed on the surface of tumor cells (e.g., EGFRvIII) ${ }^{64}$ (Figure 1). This divalent design allows BiTEs to create a molecular tether, resulting in highly-localized and specific $\mathrm{T}$ cell activation with concomitant tumor lysis. BiTEs induce immunological synapses between $\mathrm{T}$ cells and tumor cells that are indistinguishable in composition, size and subdomain arrangement from native synapses. ${ }^{65}$ Following BiTE-mediated synapse formation, $\mathrm{T}$ cells proliferate, secrete pro-inflammatory Th1-type cytokines and express surface activation markers ${ }^{66}$. BiTEs are capable of mediating serial rounds of killing ${ }^{67}$ and can trigger specific lysis from naïve $\mathrm{T}$ cells at exceedingly low concentrations and effector-to-target ratios. ${ }^{68}$ BiTEs are also capable of coopting immunosuppressive regulatory $\mathrm{T}$ cells $\left(\mathrm{T}_{\text {Regs }}\right)$, a subset of $\mathrm{CD} 4^{+} \mathrm{T}$ cells that ordinarily suppress and kill CTLs, redirecting $\mathrm{T}_{\text {Regs }}$ to efficiently lyse tumor cells. ${ }^{69,70} \mathrm{By}$ tethering cytotoxic effectors to target cells without the need for antigen presentation via the major histocompatibility complex (MHC), BiTEs can furthermore overcome tumor immune escape mechanisms, such as the downregulation of MHC. ${ }^{65}$

In a phase I clinical trial among patients with non-Hodgkin lymphoma, 7 of 7 patients receiving CD19-targeted BiTE doses as low as $0.06 \mathrm{mg} / \mathrm{m}^{2} /$ day over a one month continuous infusion period showed objective tumor regression as well as clearance of tumor from the blood, bone marrow and liver. ${ }^{71}$ This dose produced serum levels 5-fold lower than effective doses of the CD19-specific antibody rituximab, currently used clinically as standard-of-care therapy. ${ }^{72}$ Importantly, no dose-limiting cytokine release syndrome was evident; however, treatment led to the expected depletion of normal CD19-expressing B cells. Thus, a significant limitation of this promising therapeutic platform is the lack of tumor-specific targets. 
For the treatment of MG, a recently developed EGFRvIII-CD3 BiTE overcomes this limitation. ${ }^{73}$ By retargeting $\mathrm{T}$ cells against the entirely tumor specific EGFRvIII antigen, adverse effects associated with lysis of healthy tissue are averted. Pre-clinical assessment of this therapeutic demonstrates the ability to induce polyclonal T-cell proliferation and interleukin-2 (IL-2), interferon-gamma (IFN- $\gamma$ ) and tumor necrosis factor-alpha (TNF-a) secretion, exclusively in the presence of EGFRvIII-positive glioma. ${ }^{74}$ Specificity was also confirmed in standard in vitro cytotoxicity assays where the construct mediated significant tumor-specific lysis of EGFRvIII-positive glioma but did not result in cytotoxicity of EGFRvIII-negative glioma. In vivo, as few as 5 daily IV doses of EGFRvIII-targeted BiTE produced complete cures in IC tumor bearing murine models reconstituted with unstimulated human lymphocytes, and treatment of even late-stage disease in moribund mice significantly extended survival ( $\mathrm{p}<.01)$. Interestingly, the EGFRvIII-specific BiTE potently subverted highly purified $\mathrm{CD} 4^{+} \mathrm{CD} 25^{+} \mathrm{FoxP} 3^{+} \mathrm{T}_{\text {Regs }}$ to induce granzyme-mediated anti-tumor cytotoxicity, ${ }^{69}$ suggesting that BiTEs possess the unique ability to overcome mechanisms of intratumoral immunosuppression. Translation of this modality for the safe and effective care of patients with MG awaits clinical trial.

\section{Immunomodulatory targets}

In addition to redirecting $\mathrm{T}$ cells to target tumor specific antigens, mAbs can be used as immunomodulatory agents to influence the biology of the tumor immune response. This approach is based on the premise that cancer-bearing hosts have endogenous $T$ cells specific for tumor antigens, but that the activity of these cells is suboptimal, due to cancer-associated immunosuppression known to be particularly pronounced in glioma patients. ${ }^{60,75,76,77}$ To overcome this, mAbs can be engineered to possess specificity for surface receptors important in regulating the immune response.

Such immunomodulatory antibodies can serve as either blocking antibodies to prevent binding of the receptor with its endogenous ligand or as agonist antibodies to mimic the role of the receptor's endogenous ligand. In general, blocking antibodies are engineered to target receptors with an immunosuppressive role (e.g., CTLA-4, PD-1), thus preventing inhibition of the $\mathrm{T}$ cell response, while agonist antibodies target receptors with a costimulatory role (e.g., CD28, 4-1BB, OX40), thus enhancing immune effector cell activation.

\section{Blocking tumor-mediated immunosuppression with mAbs}

The immune system exhibits a number of regulatory strategies to prevent dangerous hyperactivity or autoimmunity. Specifically, T cells express inhibitory receptors on their surface that when activated serve to reduce their response to antigens. These T cell inhibitory pathways are often over-engaged in patients with glioma, due to expression of inhibitory ligands by the tumor ${ }^{78}$ and a systemic increase in $\mathrm{T}_{\text {Regs }}{ }^{79}$ Furthermore, secretion of immunosuppressive cytokines (such as TGF- $\beta$ or IL-10) by tumor cells ${ }^{80,81,82}$ causes decreased activity of $\mathrm{T}$ cells in the tumor microenvironment and promotes development of a $\mathrm{T}_{\text {Reg }}$ phenotype by naïve $\mathrm{CD} 4^{+} \mathrm{T}$ cells. There are a number of strategies currently under investigation that utilize mAbs to curtail these immunosuppressive signals (Figure 2). The use of immunomodulatory mAbs that bind to and block the signaling of inhibitory molecules 
expressed on effector $\mathrm{T}$ cells and $\mathrm{T}_{\text {Regs }}$ shows significant clinical promise. Furthermore, mAbs that bind to and block the activity of inhibitory ligands and immunosuppressive cytokines expressed by tumor cells offer the potential to combat immunosuppression directly in the tumor microenvironment.

Perhaps the most promising data in the use of immunomodulatory mAb therapies is observed in clinical trials for PD- 1 and CTLA-4 blockade. PD-1 is expressed on activated Tcells and upregulated upon prolonged antigen stimulation. ${ }^{83}$ Binding by its ligand, PD-L1, leads to decreased T cell receptor (TCR) signaling as well as downregulation of antiapoptotic molecules and pro-inflammatory cytokines. ${ }^{83}$ Tumor cells, including gliomas, exhibit increased surface expression of PD-L1 and thus shutdown T-cell activity in the tumor microenvironment. ${ }^{78,84}$ Indeed, expression of PD-1L by glioma cells and upregulation of PD-1 on peripheral T cells in glioma patients is associated with immune paralysis ${ }^{78,85}$ and correlates with disease progression. ${ }^{86,87}$ In a model of PD-L1 expressing murine glioma, Zeng et al. ${ }^{88}$ showed that PD-1 mAb blockade combined with focal radiation lead to an increase in median survival from 30 to 52 days and a 15-40\% frequency of long-term survival which corresponded to an increase in the intratumoral effector $\mathrm{T}$ cell to $\mathrm{T}_{\mathrm{Reg}}$ ratio.

Similar to PD-1, binding of CTLA-4 on T cells results in an abrogated immune response. CTLA-4 is expressed on primed T cells and competes with CD28 for binding of B7.1/2 on antigen presenting cells (APCs), thus reducing $\mathrm{T}$ cell activation and instead leading to $\mathrm{T}$ cell tolerance to antigen. ${ }^{89,90,91,92}$ Polymorphisms in CTLA-4 that alter gene expression and increase CTLA-4-mediated downregulation of T cell activity are correlated with increased susceptibility to several malignancies, ${ }^{93}, 94,95,96$ including gliomas. ${ }^{97}$ Furthermore, decreased expression of CTLA-4 on peripheral blood T cells after dendritic cell (DC) vaccination correlates with longer survival in GBM patients. ${ }^{98}$ An anti-CTLA-4 mAb (ipilimumab) provides a significant survival benefit in patients with metastatic melanoma. ${ }^{10}$ In the context of glioma, CTLA-4 mAb blockade elicited an $80 \%$ long-term survival against murine SMA-560 glioma, which corresponded to a reestablished $\mathrm{CD}^{+}{ }^{+} \mathrm{T}$ cell compartment following glioma-mediated lymphopenia. ${ }^{99}$ Additionally, CTLA-4 blockade following tumor-lysate vaccination resulted in $40 \%$ long-term survival and an enhanced antitumor immune response, ${ }^{100}$ thus implicating the potential of CTLA-4 blockade to adjuvant existing tumor vaccines. Given the potent ability for CTLA- 4 and PD-1 blockade to enhance the antitumor T cell response, a combined anti-CTLA-4 (ipilimumab) and anti-PD-1 (nivolumab) phase II trial for treatment of recurrent GBM is currently underway (NCT02017717).

In addition to its role in counteracting the CD28 costimulatory pathway in effector T cells, CTLA-4 is constitutively expressed on $\mathrm{T}_{\text {Regs }},{ }^{101,102}$ and CTLA-4 signaling in $\mathrm{T}_{\text {Regs }}$ enhances their immunosuppressive function. ${ }^{103}$ Glioma patients have an increased fraction of systemic $\mathrm{T}_{\text {Regs, }}$, which corresponds to decreased $\mathrm{T}$ cell effector activity and a shift from pro-inflammatory Th1 cytokines to an anti-inflammatory $\mathrm{Th} 2$ milieu. ${ }^{79}$ In addition to an increase in systemic $\mathrm{T}_{\text {Regs }}$, intratumoral $\mathrm{T}_{\text {Reg }}$ numbers increase profoundly in low and high grade astrocytomas. ${ }^{79}, 104,105$ A number of glioma immunotherapy strategies are thus being explored to directly and specifically block $\mathrm{T}_{\text {Reg }}$ activity with mAbs, including CTLA-4 
blockade. Vom Berg et al. showed that CTLA-4 expression increases on $\mathrm{T}_{\text {Regs }}$ in gliomabearing mice ${ }^{106}$ and that intratumoral CTLA- $4 \mathrm{mAb}$ blockade, combined with intratumoral IL-12, leads to enhanced survival compared to either therapy alone. This prolonged survival was accompanied by an intratumoral shift from a high population of FoxP3 ${ }^{+} \mathrm{T}_{\mathrm{Reg}}$ cells to a high population of pro-inflammatory IFN- $\gamma$-producing $\mathrm{CD} 4^{+}$cells.

Antibodies against CD25, a subunit of the IL-2 receptor present on the surface of $\mathrm{T}_{\text {Regs }}$, also shows promise. El Andaloussi et al. showed that anti-CD25 mAb blockade leads to a decrease in the intratrumoral $\mathrm{T}_{\text {Reg }}$ compartment from $46 \%$ to $6 \%$, corresponding to an increase in median survival from 27 to 40 days in mice harboring IC glial (GL261) tumors. ${ }^{107}$ Further studies confirmed that $\mathrm{CD} 25$ blocking mAb leads to prolonged survival in glioma-bearing mice, and that CD25 blockade works not only by reducing $\mathrm{T}_{\text {Reg }}$ numbers, but also by inhibiting the suppressive activity of the remaining $\mathrm{T}_{\text {Reg }}$ compartment. ${ }^{79} \mathrm{Of}$ note, combined IC and systemic administration of anti-CD25 lead to complete survival in GL261-bearing mice, compared to a lower cure rate of $40 \%$ in mice receiving only systemic anti-CD25, ${ }^{108}$ suggesting that direct targeting of intratumoral $\mathrm{T}_{\text {Regs }}$ may be integral for optimal antitumor efficacy. CD25 blockade also synergizes with CTLA-4 blockade, reducing $\mathrm{T}_{\mathrm{Reg}}$ numbers and prolonging survival in glioma-bearing mice. ${ }^{109}$ The enhanced immune response observed upon combination therapy was tumor-specific, sparing surrounding areas of healthy, eloquent brain tissue.

Importantly, the proportion of systemic functional $\mathrm{T}_{\mathrm{Regs}}$ increases significantly following standard-of-care temozolomide (TMZ) therapy, ${ }^{110}$ a treatment known to provide a significant survival benefit among patients with newly diagnosed GMB. ${ }^{6,8}$ When combined with TMZ, however, mAb mediated CD25 blockade curbs the increased $\mathrm{T}_{\text {Reg }}$ fraction, resulting in enhanced antitumor immune responses in mice and humans. ${ }^{111}$

Immunotherapeutic approaches for the treatment of MG can also result in an increase in the proportion of functional $\mathrm{T}_{\text {Regs }}$. For example, administration of an RNA-loaded DC vaccine against murine glioma was shown to increase the splenic $\mathrm{T}_{\text {Reg }}$ compartment by $12 \%$, but $\mathrm{T}_{\text {Reg }}$ depletion via an anti-CD25 mAb in combination with the DC vaccine lead to increased antitumor efficacy compared to vaccine alone. ${ }^{112}$ Clinical trials have likewise demonstrated that the addition of a humanized anti-CD25 mAb (daclizumab) to immunotherapeutic platforms for the treatment of GBM leads to a decreased proportion of $\mathrm{T}_{\text {Regs }}$ and more effective outcomes. Daclizumab given 3 weeks after the first TMZ cycle, concomitant with adoptive transfer of naïve lymphocytes and a pp65 DC vaccine for example, leads to sustained $\mathrm{T}_{\mathrm{Reg}}$ depletion and an increase in antigen-specific $\mathrm{T}$ cells with progression free survival exceeding 24 months in 4 of 6 patients. ${ }^{111}$ Additionally, daclizumab combined with EGFRvIII peptide vaccination ${ }^{113}$ was well tolerated in a randomized pilot study and resulted in a significant decrease in the peripheral $\mathrm{T}_{\text {Reg }}$ compartment. ${ }^{114}$

Alternative strategies to combat the potent immunosuppression observed in patients with MG attempt to modify the immunosuppressive climate of the tumor microenvironment. To this end, TGF- $\beta$ has surfaced as a promising target for mAb blockade. TGF- $\beta$, secreted by glioma cells and microglia, promotes tumor growth via enhancing tumor cell migration and angiogenesis. ${ }^{115,116}$ TGF- $\beta$ furthermore contributes to the immunosuppressive tumor microenvironment by inducing a $\mathrm{T}_{\mathrm{Reg}}$ phenotype in naïve $\mathrm{CD}^{+}$cells ${ }^{117}, 118,119$ and 
suppresses cytotoxic immune responses. ${ }^{82,120,121}$ In preclinical studies, TGF- $\beta$ blockade with a murine $\mathrm{mAb}, 1 \mathrm{D} 11$, increased antitumor efficacy of a glioma-associated-antigen (GAA) vaccine, and lead to increased infiltration and persistence of anti-GAA CTLs, decreased the proportion of $\mathrm{T}_{\text {Regs }}$, and shifted the intratumoral cytokine production to that of a pro-inflammatory Th1 profile. ${ }^{122} 1 \mathrm{D} 11$ administration was additionally shown to reduce infiltration and invasion of glioma cells into normal brain tissue. ${ }^{123}$ A humanized TGF- $\beta$ $\mathrm{mAb}$ (fresolimumab) currently under clinical investigation for breast cancer, mesothelioma and melanoma has likewise shown promising results. ${ }^{124}$ The use of fresolimumab among patients with MG is currently under investigation in a phase II clinical trial (NCT01472731).

Given the pre-clinical and clinical data that continues to accumulate, it is evident that abrogating glioma-mediated immunosuppression will undoubtedly be a critical component of therapeutic intervention among patients with MG. Given their exquisite target binding specificity, mAbs are particularly well suited for this role. As we continue to uncover details of the complex relationship between IC malignancies and systemic immunosuppression, new therapeutic targets will likely surface.

\section{Agonist mAbs for $T$ cell costimulatory pathways}

Optimal activation of naïve T cells requires both a strong interaction between the TCR and peptide-bound MHC, as well as interaction with costimulatory ligands expressed by APCs. Costimulation in the presence of TCR engagement results in increased proliferation, cytokine production and enhanced survival (for a review on $\mathrm{T}$ cell costimulatory pathways, see reference ${ }^{125}$ ). During a functional immune response, costimulatory ligands are upregulated on activated APCs and displayed during antigen-presentation to T cells. ${ }^{126,127}$ However, APC costimulatory activity is often abrogated in cancer-bearing hosts, which can result in T cell apoptosis or anergy to tumor antigens. ${ }^{128,}{ }^{129}$ Agonist mAbs for costimulatory receptors on $\mathrm{T}$ cells offer a promising strategy for overcoming aberrant APC activity and ensuring delivery of the vital costimulatory signal (Figure 3).

Many costimulatory pathways have been described over the past 30 years, with the highly characterized CD28 signal canonically considered to be the most potent and necessary for a functional $\mathrm{T}$ cell response. ${ }^{130}$ The early therapeutic promise of enhancing this costimulatory pathway was observed in clinical studies evaluating the efficacy of adding exogenously delivered CD28 signals to tumor vaccine platforms. $131,132,133,134,135,136$ The results of such studies lead to the development of a CD28 superagonist mAb (TGN1412), capable of fully activating T cells via the CD28 receptor in the absence of TCR and peptide bound MHC interaction, and its evaluation as a therapy for B cell lymphoma. All patients enrolled in the first phase I trial of TGN1412, however, suffered severe and life-threatening adverse effects due to CD28-mediated cytokine storm. ${ }^{63}$ While this finding has curtailed further evaluation of CD28 mAbs, given the promise of earlier studies implicating the role of costimulatory signals as potential tumor vaccine adjuvants, mAbs targeting alternative costimulatory pathways are cautiously being pursued.

In the context of immunotherapy for MG, the evaluation of costimulatory mAbs is still in its infancy. Such agonist antibodies, however, demonstrate great promise in clinical trials for 
the treatment of other cancers and may prove especially useful in the treatment of MG.

Targeting costimulatory members of the tumor necrosis factor receptor (TNFR) superfamily specifically upregulated on activated T cells, OX40 on CD4 ${ }^{+}$cells 137,138 and 4-1BB on $\mathrm{CD}^{+}$cells ${ }^{139,140}$ has proven particularly effective in pre-clinical glioma models. The use of $\mathrm{mAbs}$ for $\mathrm{OX} 40^{141}$ and $4-1 \mathrm{BB}^{142}$ as monotherapies for murine glioma resulted in a $50 \%$ cure rate and increased median survival from 31 days to 42 days, respectively. In a separate study, addition of an anti-4-1BB antibody enhanced the antitumor activity of T cells primed with glioma-lysate pulsed DCs. ${ }^{143}$ In a recent study by Murphy et al., ${ }^{144}$ four costimulatory targets were compared as treatments for murine glioma. The ligands for OX40, CD28, 4-1BB, and glucocorticoid-induced tumor necrosis factor receptor (GITR) were fused to the Fc portion of human Ig to generate surrogate agonist antibodies, and these agonist treatments were combined with tumor lysate vaccines. The authors found that the OX40LFc/lysate combined treatment had the highest efficacy (70\% cure rates) compared to the other three fusion proteins, which yielded no enhanced survival. The efficacy in targeting OX40 and 4-1BB is likely due to their role in augmenting the tumoricidal activity of activated tumor-specific $\mathrm{T}$ cells. Interestingly, given these data, it appears that targeting costimulatory pathways specific to either $\mathrm{CD} 4^{+}$or $\mathrm{CD}^{+} \mathrm{T}$ cells may yield an enhanced antitumor response. Strikingly, the addition of standard-of-care TMZ therapy to the OX40LFc/lysate vaccine regiment resulted in $100 \%$ tumor regression. ${ }^{144}$ Similarly, the antitumor effect of the 4-1BB agonist was significantly enhanced by the addition of radiotherapy (median survival was increased to 114 days). ${ }^{142} \mathrm{TMZ}$ and radiation are presumed to enhance tumor antigen presentation via upregulation of tumor MHC expression ${ }^{145,146}$ and shedding of antigens by dead tumor cells; ${ }^{147,148,149}$ this putative increase in antigen presentation would provide one of the two necessary signals for an immune response, while the agonist mAb ensures delivery of the second signal.

Indeed, given promising preclinical findings, ${ }^{150,151,152,153}$ there are a number of agonist OX40 and 4-1BB mAbs currently in clinical development. Two clinical trials were recently initiated to investigate anti-OX40 mAb therapy in combination with standard-of-care chemotherapy and radiation therapy in prostate and breast cancer patients (NCT01303705; NCT01862900). A humanized anti-4-1BB mAb, BMS-663513, was tested in a phase I study in patients with advanced melanoma and yielded partial responses in 3 out 4 patients, as well as an increased percentage of activated $\mathrm{CD}^{+} \mathrm{T}$ cells in peripheral blood. ${ }^{154}$ Another humanized 4-1BB agonist is currently in a clinical trial as a single agent in patients with solid tumors (NCT01307267). It will be of interest to evaluate these mAbs as treatments for human gliomas.

There are a number of other costimulatory molecules for which agonist mAbs have yet to be thoroughly evaluated in the setting of $\mathrm{MG}$, but that have shown promise in other tumor types, including GITR, CD27 and CD40, additional members of the TNFR superfamily. Similar to OX40 and 4-1BB, GITR is expressed on activated T cells. ${ }^{155}$ Anti-GITR agonist mAbs have been shown to induce rejection of several murine syngeneic tumors, ${ }^{156,157}$ but like OX40, GITR agonism may proceed in a CD4-mediated fashion, ${ }^{158}$ a facet that is not yet clearly understood in the context of glioma immunotherapy. Indeed, an anti-human GITR 
mAb, TRX518, is currently in a phase I trial for advanced stage melanoma and other solid tumors, including CNS malignancies (NCT01239134).

Unlike OX40, 4-1BB and GITR, CD27 is expressed on both naïve and activated T cells, ${ }^{159}$ suggesting its role in $\mathrm{T}$ cell priming early in the immune response. Keller et al. ${ }^{160}$ showed that constitutive expression of the CD27 ligand (CD70) on DCs enabled T cell priming in the absence of any adjuvant, suggesting that this costimulatory pathway is perhaps one of the more critical ones for adaptive immunity. In the context of GBM, Miller et al. ${ }^{161}$ have demonstrated that intratumoral soluble CD70 significantly prolonged survival of tumorbearing mice in a CD8-dependent fashion. Furthermore, a CD27 agonist mAb was reported to have efficacy as a monotherapy in a variety of murine tumor models ${ }^{162}$ and is now in early clinical trials for the treatment of hematologic malignancies and solid tumors (NCT01460134). Our group is currently investigating CD27 agonist mAb therapy for the treatment of MG; we have observed promising results in preclinical murine glioma models.

In addition to providing costimulatory signals directly to $\mathrm{T}$ cells, promoting activation of APCs through the use of agonist mAbs for CD40 is yet another attractive strategy for enhancing the antitumor immune response. CD40 is constitutively expressed by immature DCs, and its ligation by CD40L results in DC maturation and upregulation of costimulatory ligands, making it crucial for functional antigen presentation. ${ }^{163,} 164$ Indeed, CD40 agonist mAbs have anti-tumor effects in a variety of murine tumor models. ${ }^{165,166,167}$ Interestingly, CD40 stimulation in gliomas was found to directly inhibit cell proliferation through $\mathrm{NF \kappa B}$ signaling and TNFa production. ${ }^{168}$ These studies make mAb targeting of CD40 a promising strategy from both an immunomodulatory perspective and as a direct cancer therapeutic. An anti-CD40 mAb, CP-870,893, has shown anti-tumor activity mediated by CD40-expressing macrophages; a clinical trial evaluating the effect of CP-870,893 in combination with antiCTLA-4 (tremilumumab) in melanoma patients is currently underway (NCT01103635).

\section{Discussion}

Due to their inherent capacity to be engineered for specificity against nearly any biological target, antibodies provide a particularly promising immunotherapeutic modality for MG. Capable of being formulated as an off-the-shelf therapeutic, antibodies furthermore offer a distinct advantage over many other forms of anti-cancer immunotherapy that require costly preparation of patient-specific vaccines. Three general approaches for antibody based immunotherapy for MG have emerged: 1) redirecting immune effector cells against tumor antigens to mediate tumor cell death, through bispecific antibodies such as BiTEs directed against tumor specific mutations for example, 2) blocking immunosuppressive signals by targeting of surface molecules on immune cells or soluble mediators, and 3) and enhancing immune effector cell activity via antibodies agonistic for co-stimulatory receptors.

Preclinical and clinical studies in MG have brought validation to each of these approaches.

Bispecific antibody based therapy against the tumor specific antigen EGFRvIII elicits a highly potent and specific tumoricidal response and clinical trials investigating bispecific antibody based therapy ${ }^{71,169,170}$ demonstrate safety and efficacy against forms of cancer highly refractory to conventional therapy. This approach is limited only by the paucity of 
glioma-specific targets. As more glioma-specific targets, such as EGFRvIII, are uncovered there will be additional opportunity for therapeutic intervention. Still, we have seen that that in addition to eradicating well-established EGFRvIII-positive GBM, EGFRvIII-specific antibody-redirected $\mathrm{T}$ cells produce long-lasting immunity against EGFRvIII-negative tumor cells without evidence of autoimmune toxicity, ${ }^{171}$ suggesting that this approach is superior to EGFRvIII-targeted vaccines that are limited by antigen escape,,${ }^{172}$ and thus warranting further investigation through clinical trial.

Using mAbs to modulate the biology of the anti-tumor immune response likewise holds promise for the treatment of MG. This approach has proven safe and effective in the treatment of a variety of different solid tumors. In particular, combined blockade of the immunosuppressive CTLA-4 and PD-1 pathways has garnered much attention recently given the success in clinical trials for the treatment of advanced melanoma; ${ }^{173}, 174,175$ data generated from the ongoing clinical study of such combination therapy for MG is awaited. Antibody based CD25 blockade will also potentially play a significant role in immunotherapeutic intervention for MG, given its ability to decrease the number and activity of $\mathrm{T}_{\text {Regs }}$, a highly immunosuppressive cell fraction that increases with standard-ofcare TMZ therapy for MG. ${ }^{110}$ Several co-stimulatory molecules on the surface of immune effector cells are also attractive targets for the reversal of immunosuppression and antibody based therapy for MG. Indeed, clinical trials investigating this approach in several forms of solid tumors are underway and pre-clinical data in the context of therapy for MG demonstrate encouraging results. The availability of transgenic animal models expressing functional human co-stimulatory receptors will be critical, however, in order to allow for comprehensive pre-clinical assessment of safety in fully immunocompetent, pharmacologically responsive animals.

It is evident that given the profound immunosuppression among patients with $\mathrm{MG}$, a multitude of immunosuppressive pathways are amenable to antibody based blockade or activation. Large-scale clinical trials are necessary in order to ascertain which therapeutic targets provide the safest and most effective anti-tumor immunotherapy for patients with MG. It is likely that optimal therapy for MG may be obtained via synergistic immunotherapeutic combinations. There is also great potential for personalized therapy, tailored to target patient specific tumor mutations (ex. EGFRvIII-specific BiTE) and to reverse the immunosuppressive factors most prevalent for a given patient.

Despite advances in the standard of care for MG, the survival statistics among patients remains dismal. Antibody-based immunotherapy, however, by virtue of allowing for tumor cell specific lysis, permits for therapy aggressive and prolonged enough to safely eliminate all malignant cells while sparing eloquent, healthy CNS and peripheral tissue. Continued clinical investigation is necessary in order to avail antibody based immunotherapeutic options to patients with MG.

\section{Acknowledgments}

We would like to acknowledge our patients who are an endless source of inspiration; our family and friends for their continuous support; Elspeth Wilman for her artistic contributions; and Gary Archer, Xiuyu Cui, Pamela Norberg, Luis Sanchez-Perez, Elizabeth Reap, Robert Schmittling, Scott Szafranski, and Weihua Xie. 


\section{References}

1. United States Cancer Statistics. National Program of Cancer Registries. 2010. Available from: http://appsncedcdegov/uscs/.

2. Estimated Number of New Cancer Cases and Deaths by Sex, US. 2014 Available from: http:// wwwcancerorg.

3. Kelly PJ. Stereotactic resection and its limitations in glial neoplasms. Stereotact Funct Neurosurg. 1992; 59:84-91. [PubMed: 1295051]

4. Walker MD, Green SB, Byar DP, Alexander E Jr, Batzdorf U, Brooks WH, et al. Randomized comparisons of radiotherapy and nitrosoureas for the treatment of malignant glioma after surgery. The New England journal of medicine. 1980; 303:1323-1329. [PubMed: 7001230]

5. Reardon DA, Akabani G, Coleman RE, Friedman AH, Friedman HS, Herndon JE 2nd, et al. Salvage radioimmunotherapy with murine iodine-131-labeled antitenascin monoclonal antibody 81C6 for patients with recurrent primary and metastatic malignant brain tumors: phase II study results. Journal of clinical oncology : official journal of the American Society of Clinical Oncology. 2006; 24:115-122. [PubMed: 16382120]

6. Stupp R, Mason WP, van den Bent MJ, Weller M, Fisher B, Taphoorn MJ, et al. Radiotherapy plus concomitant and adjuvant temozolomide for glioblastoma. The New England journal of medicine. 2005; 352:987-996. [PubMed: 15758009]

7. Vredenburgh JJ, Desjardins A, Herndon JE 2nd, Marcello J, Reardon DA, Quinn JA, et al. Bevacizumab plus irinotecan in recurrent glioblastoma multiforme. Journal of clinical oncology : official journal of the American Society of Clinical Oncology. 2007; 25:4722-4729. [PubMed: 17947719]

8. Stupp R, Hegi ME, Mason WP, van den Bent MJ, Taphoorn MJ, Janzer RC, et al. Effects of radiotherapy with concomitant and adjuvant temozolomide versus radiotherapy alone on survival in glioblastoma in a randomised phase III study: 5-year analysis of the EORTC-NCIC trial. Lancet Oncol. 2009; 10:459-466. [PubMed: 19269895]

9. Imperato JP, Paleologos NA, Vick NA. Effects of treatment on long-term survivors with malignant astrocytomas. Annals of neurology. 1990; 28:818-822. [PubMed: 2178330]

10. Hodi FS, O'Day SJ, McDermott DF, Weber RW, Sosman JA, Haanen JB, et al. Improved survival with ipilimumab in patients with metastatic melanoma. The New England journal of medicine. 2010; 363:711-723. [PubMed: 20525992]

11. Kantoff PW, Higano CS, Shore ND, Berger ER, Small EJ, Penson DF, et al. Sipuleucel-T immunotherapy for castration-resistant prostate cancer. The New England journal of medicine. 2010; 363:411-422. [PubMed: 20818862]

12. Boder ET, Midelfort KS, Wittrup KD. Directed evolution of antibody fragments with monovalent femtomolar antigen-binding affinity. Proc Natl Acad Sci U S A. 2000; 97:10701-10705. [PubMed: 10984501]

13. Hoogenboom HR. Selecting and screening recombinant antibody libraries. Nature biotechnology. 2005; 23:1105-1116.

14. Lonberg N. Fully human antibodies from transgenic mouse and phage display platforms. Current opinion in immunology. 2008; 20:450-459. [PubMed: 18606226]

15. Gaston RS, Deierhoi MH, Patterson T, Prasthofer E, Julian BA, Barber WH, et al. OKT3 first-dose reaction: association with $\mathrm{T}$ cell subsets and cytokine release. Kidney international. 1991; 39:141148. [PubMed: 1900552]

16. Hansel TT, Kropshofer H, Singer T, Mitchell JA, George AJ. The safety and side effects of monoclonal antibodies. Nature reviews Drug discovery. 2010; 9:325-338.

17. Reynolds JC, Del Vecchio S, Sakahara H, Lora ME, Carrasquillo JA, Neumann RD, et al. Antimurine antibody response to mouse monoclonal antibodies: clinical findings and implications. International journal of radiation applications and instrumentation Part B, Nuclear medicine and biology. 1989; 16:121-125.

18. Carter PJ. Potent antibody therapeutics by design. Nat Rev Immunol. 2006; 6:343-357. [PubMed: 16622479] 
19. Kuus-Reichel K, Grauer LS, Karavodin LM, Knott C, Krusemeier M, Kay NE. Will immunogenicity limit the use, efficacy, and future development of therapeutic monoclonal antibodies? Clinical and diagnostic laboratory immunology. 1994; 1:365-372. [PubMed: 8556470]

20. Mascelli MA, Zhou H, Sweet R, Getsy J, Davis HM, Graham M, et al. Molecular, biologic, and pharmacokinetic properties of monoclonal antibodies: impact of these parameters on early clinical development. Journal of clinical pharmacology. 2007; 47:553-565. [PubMed: 17379759]

21. Male, DK. Immunology of Brain Endothelium and the Blood-Brain Barrier. In: Bradbury, MWB., editor. Physiology and Pharmacology of the Blood-Brain Barrier. Berlin: Springer; 1992. p. 397-415.

22. Lee J, Lund-Smith C, Borboa A, Gonzalez AM, Baird A, Eliceiri BP. Glioma-induced remodeling of the neurovascular unit. Brain research. 2009; 1288:125-134. [PubMed: 19595677]

23. Bourdon MA, Coleman RE, Blasberg RG, Groothuis DR, Bigner DD. Monoclonal antibody localization in subcutaneous and intracranial human glioma xenografts: paired-label and imaging analysis. Anticancer research. 1984; 4:133-140. [PubMed: 6465851]

24. Bullard DE, Adams CJ, Coleman RE, Bigner DD. In vivo imaging of intracranial human glioma xenografts comparing specific with nonspecific radiolabeled monoclonal antibodies. Journal of neurosurgery. 1986; 64:257-262. [PubMed: 3944636]

25. Scott AM, Lee FT, Tebbutt N, Herbertson R, Gill SS, Liu Z, et al. A phase I clinical trial with monoclonal antibody ch806 targeting transitional state and mutant epidermal growth factor receptors. Proc Natl Acad Sci U S A. 2007; 104:4071-4076. [PubMed: 17360479]

26. Zalutsky MR, Moseley RP, Coakham HB, Coleman RE, Bigner DD. Pharmacokinetics and tumor localization of 131I-labeled anti-tenascin monoclonal antibody 81C6 in patients with gliomas and other intracranial malignancies. Cancer Res. 1989; 49:2807-2813. [PubMed: 2469537]

27. Lengauer C, Kinzler KW, Vogelstein B. Genetic instabilities in human cancers. Nature. 1998; 396:643-649. [PubMed: 9872311]

28. Aldape KD, Ballman K, Furth A, Buckner JC, Giannini C, Burger PC, et al. Immunohistochemical detection of EGFRvIII in high malignancy grade astrocytomas and evaluation of prognostic significance. Journal of neuropathology and experimental neurology. 2004; 63:700-707. [PubMed: 15290895]

29. Ekstrand AJ, James CD, Cavenee WK, Seliger B, Pettersson RF, Collins VP. Genes for epidermal growth factor receptor, transforming growth factor alpha, and epidermal growth factor and their expression in human gliomas in vivo. Cancer Res. 1991; 51:2164-2172. [PubMed: 2009534]

30. Frederick L, Wang XY, Eley G, James CD. Diversity and frequency of epidermal growth factor receptor mutations in human glioblastomas. Cancer Res. 2000; 60:1383-1387. [PubMed: 10728703]

31. Humphrey PA, Wong AJ, Vogelstein B, Friedman HS, Werner MH, Bigner DD, et al. Amplification and expression of the epidermal growth factor receptor gene in human glioma xenografts. Cancer Res. 1988; 48:2231-2238. [PubMed: 3258189]

32. Sugawa N, Ekstrand AJ, James CD, Collins VP. Identical splicing of aberrant epidermal growth factor receptor transcripts from amplified rearranged genes in human glioblastomas. Proc Natl Acad Sci U S A. 1990; 87:8602-8606. [PubMed: 2236070]

33. Wikstrand CJ, Hale LP, Batra SK, Hill ML, Humphrey PA, Kurpad SN, et al. Monoclonal antibodies against EGFRvIII are tumor specific and react with breast and lung carcinomas and malignant gliomas. Cancer Res. 1995; 55:3140-3148. [PubMed: 7606735]

34. Wikstrand CJ, McLendon RE, Friedman AH, Bigner DD. Cell surface localization and density of the tumor-associated variant of the epidermal growth factor receptor, EGFRvIII. Cancer Res. 1997; 57:4130-4140. [PubMed: 9307304]

35. Wong AJ, Ruppert JM, Bigner SH, Grzeschik CH, Humphrey PA, Bigner DS, et al. Structural alterations of the epidermal growth factor receptor gene in human gliomas. Proc Natl Acad Sci U S A. 1992; 89:2965-2969. [PubMed: 1557402]

36. Cunningham MP, Essapen S, Thomas H, Green M, Lovell DP, Topham C, et al. Coexpression, prognostic significance and predictive value of EGFR, EGFRvIII and phosphorylated EGFR in colorectal cancer. International journal of oncology. 2005; 27:317-325. [PubMed: 16010411] 
37. Garcia de Palazzo IE, Adams GP, Sundareshan P, Wong AJ, Testa JR, Bigner DD, et al. Expression of mutated epidermal growth factor receptor by non-small cell lung carcinomas. Cancer Res. 1993; 53:3217-3220. [PubMed: 8391918]

38. Ge H, Gong X, Tang CK. Evidence of high incidence of EGFRvIII expression and coexpression with EGFR in human invasive breast cancer by laser capture microdissection and immunohistochemical analysis. Int J Cancer. 2002; 98:357-361. [PubMed: 11920586]

39. Moscatello DK, Holgado-Madruga M, Godwin AK, Ramirez G, Gunn G, Zoltick PW, et al. Frequent expression of a mutant epidermal growth factor receptor in multiple human tumors. Cancer Res. 1995; 55:5536-5539. [PubMed: 7585629]

40. Olapade-Olaopa EO, Moscatello DK, MacKay EH, Horsburgh T, Sandhu DP, Terry TR, et al. Evidence for the differential expression of a variant EGF receptor protein in human prostate cancer. British journal of cancer. 2000; 82:186-194. [PubMed: 10638988]

41. Sok JC, Coppelli FM, Thomas SM, Lango MN, Xi S, Hunt JL, et al. Mutant epidermal growth factor receptor (EGFRvIII) contributes to head and neck cancer growth and resistance to EGFR targeting. Clin Cancer Res. 2006; 12:5064-5073. [PubMed: 16951222]

42. Libermann TA, Nusbaum HR, Razon N, Kris R, Lax I, Soreq H, et al. Amplification, enhanced expression and possible rearrangement of EGF receptor gene in primary human brain tumours of glial origin. Nature. 1985; 313:144-147. [PubMed: 2981413]

43. Bigner SH, Humphrey PA, Wong AJ, Vogelstein B, Mark J, Friedman HS, et al. Characterization of the epidermal growth factor receptor in human glioma cell lines and xenografts. Cancer Res. 1990; 50:8017-8022. [PubMed: 2253244]

44. Humphrey PA, Wong AJ, Vogelstein B, Zalutsky MR, Fuller GN, Archer GE, et al. Anti-synthetic peptide antibody reacting at the fusion junction of deletion-mutant epidermal growth factor receptors in human glioblastoma. Proc Natl Acad Sci U S A. 1990; 87:4207-4211. [PubMed: 1693434]

45. Batra SK, Castelino-Prabhu S, Wikstrand CJ, Zhu X, Humphrey PA, Friedman HS, et al. Epidermal growth factor ligand-independent, unregulated, cell-transforming potential of a naturally occurring human mutant EGFRvIII gene. Cell growth \& differentiation : the molecular biology journal of the American Association for Cancer Research. 1995; 6:1251-1259. [PubMed: 8845302]

46. Chu CT, Everiss KD, Wikstrand CJ, Batra SK, Kung HJ, Bigner DD. Receptor dimerization is not a factor in the signalling activity of a transforming variant epidermal growth factor receptor (EGFRvIII). The Biochemical journal. 1997; 324(Pt 3):855-861. [PubMed: 9210410]

47. Huang HS, Nagane M, Klingbeil CK, Lin H, Nishikawa R, Ji XD, et al. The enhanced tumorigenic activity of a mutant epidermal growth factor receptor common in human cancers is mediated by threshold levels of constitutive tyrosine phosphorylation and unattenuated signaling. The Journal of biological chemistry. 1997; 272:2927-2935. [PubMed: 9006938]

48. Nishikawa R, Ji XD, Harmon RC, Lazar CS, Gill GN, Cavenee WK, et al. A mutant epidermal growth factor receptor common in human glioma confers enhanced tumorigenicity. Proc Natl Acad Sci U S A. 1994; 91:7727-7731. [PubMed: 8052651]

49. Boockvar JA, Kapitonov D, Kapoor G, Schouten J, Counelis GJ, Bogler O, et al. Constitutive EGFR signaling confers a motile phenotype to neural stem cells. Molecular and cellular neurosciences. 2003; 24:1116-1130. [PubMed: 14697673]

50. Pedersen MW, Tkach V, Pedersen N, Berezin V, Poulsen HS. Expression of a naturally occurring constitutively active variant of the epidermal growth factor receptor in mouse fibroblasts increases motility. Int J Cancer. 2004; 108:643-653. [PubMed: 14696090]

51. Lammering G, Hewit TH, Holmes M, Valerie K, Hawkins W, Lin PS, et al. Inhibition of the type III epidermal growth factor receptor variant mutant receptor by dominant-negative EGFR-CD533 enhances malignant glioma cell radiosensitivity. Clin Cancer Res. 2004; 10:6732-6743. [PubMed: 15475464]

52. Montgomery RB, Guzman J, O'Rourke DM, Stahl WL. Expression of oncogenic epidermal growth factor receptor family kinases induces paclitaxel resistance and alters beta-tubulin isotype expression. The Journal of biological chemistry. 2000; 275:17358-17363. [PubMed: 10749863] 
53. Nagane M, Narita Y, Mishima K, Levitzki A, Burgess AW, Cavenee WK, et al. Human glioblastoma xenografts overexpressing a tumor-specific mutant epidermal growth factor receptor sensitized to cisplatin by the AG1478 tyrosine kinase inhibitor. Journal of neurosurgery. 2001; 95:472-479. [PubMed: 11565870]

54. Heimberger AB, Hlatky R, Suki D, Yang D, Weinberg J, Gilbert M, et al. Prognostic effect of epidermal growth factor receptor and EGFRvIII in glioblastoma multiforme patients. Clin Cancer Res. 2005; 11:1462-1466. [PubMed: 15746047]

55. Inda MM, Bonavia R, Mukasa A, Narita Y, Sah DW, Vandenberg S, et al. Tumor heterogeneity is an active process maintained by a mutant EGFR-induced cytokine circuit in glioblastoma. Genes \& development. 2010; 24:1731-1745. [PubMed: 20713517]

56. Al-Nedawi K, Meehan B, Micallef J, Lhotak V, May L, Guha A, et al. Intercellular transfer of the oncogenic receptor EGFRvIII by microvesicles derived from tumour cells. Nature cell biology. 2008; 10:619-624.

57. Emlet DR, Gupta P, Holgado-Madruga M, Del Vecchio CA, Mitra SS, Han SY, et al. Targeting a Glioblastoma Cancer Stem Cell Population Defined by EGF Receptor Variant III. Cancer Res. 2013

58. Morgan RA, Johnson LA, Davis JL, Zheng Z, Woolard KD, Reap EA, et al. Recognition of glioma stem cells by genetically modified T cells targeting EGFRvIII and development of adoptive cell therapy for glioma. Human gene therapy. 2012; 23:1043-1053. [PubMed: 22780919]

59. Dirks PB. Cancer: stem cells and brain tumours. Nature. 2006; 444:687-688. [PubMed: 17151644]

60. Dix AR, Brooks WH, Roszman TL, Morford LA. Immune defects observed in patients with primary malignant brain tumors. Journal of neuroimmunology. 1999; 100:216-232. [PubMed: 10695732]

61. Rossi ML, Hughes JT, Esiri MM, Coakham HB, Brownell DB. Immunohistological study of mononuclear cell infiltrate in malignant gliomas. Acta neuropathologica. 1987; 74:269-277. [PubMed: 3314311]

62. Dudley ME, Rosenberg SA. Adoptive-cell-transfer therapy for the treatment of patients with cancer. Nature reviews Cancer. 2003; 3:666-675.

63. Suntharalingam G, Perry MR, Ward S, Brett SJ, Castello-Cortes A, Brunner MD, et al. Cytokine storm in a phase 1 trial of the anti-CD28 monoclonal antibody TGN1412. The New England journal of medicine. 2006; 355:1018-1028. [PubMed: 16908486]

64. Baeuerle PA, Kufer P, Lutterbuse R. Bispecific antibodies for polyclonal T-cell engagement. Current opinion in molecular therapeutics. 2003; 5:413-419. [PubMed: 14513685]

65. Offner S, Hofmeister R, Romaniuk A, Kufer P, Baeuerle PA. Induction of regular cytolytic T cell synapses by bispecific single-chain antibody constructs on MHC class I-negative tumor cells. Molecular immunology. 2006; 43:763-771. [PubMed: 16360021]

66. Mack M, Gruber R, Schmidt S, Riethmuller G, Kufer P. Biologic properties of a bispecific singlechain antibody directed against 17-1A (EpCAM) and CD3: tumor cell-dependent T cell stimulation and cytotoxic activity. Journal of immunology. 1997; 158:3965-3970.

67. Hoffmann P, Hofmeister R, Brischwein K, Brandl C, Crommer S, Bargou R, et al. Serial killing of tumor cells by cytotoxic T cells redirected with a CD19-/CD3-bispecific single-chain antibody construct. Int J Cancer. 2005; 115:98-104. [PubMed: 15688411]

68. Dreier T, Lorenczewski G, Brandl C, Hoffmann P, Syring U, Hanakam F, et al. Extremely potent, rapid and costimulation-independent cytotoxic $\mathrm{T}$-cell response against lymphoma cells catalyzed by a single-chain bispecific antibody. Int J Cancer. 2002; 100:690-697. [PubMed: 12209608]

69. Choi BD, Gedeon PC, Herndon JE 2nd, Archer GE, Reap EA, Sanchez-Perez L, et al. Human Regulatory T Cells Kill Tumor Cells through Granzyme-Dependent cytotoxicity Upon Retargeting with a Bispecific Antibody. Cancer Immunol Res. 2013; 1:163-167. [PubMed: 24570975]

70. Choi BD, Gedeon PC, Sanchez-Perez L, Bigner DD, Sampson JH. Regulatory T cells are redirected to kill glioblastoma by an EGFRvIII-targeted bispecific antibody. Oncoimmunology. 2013; 2:e26757. [PubMed: 24475376]

71. Bargou R, Leo E, Zugmaier G, Klinger M, Goebeler M, Knop S, et al. Tumor regression in cancer patients by very low doses of a T cell-engaging antibody. Science. 2008; 321:974-977. [PubMed: 18703743] 
72. Maloney DG, Grillo-Lopez AJ, Bodkin DJ, White CA, Liles TM, Royston I, et al. IDEC-C2B8: results of a phase I multiple-dose trial in patients with relapsed non-Hodgkin's lymphoma.[see comment]. Journal of clinical oncology : official journal of the American Society of Clinical Oncology. 1997; 15:3266-3274. [PubMed: 9336364]

73. Gedeon PC, Choi BD, Hodges TR, Mitchell DA, Bigner DD, Sampson JH. An EGFRvIII-targeted bispecific T-cell engager overcomes limitations of the standard of care for glioblastoma. Expert Review of Clinical Pharmacology. 2013; 6:375-386. [PubMed: 23927666]

74. Choi BD, Kuan CT, Cai M, Archer GE, Mitchell DA, Gedeon PC, et al. Systemic administration of a bispecific antibody targeting EGFRvIII successfully treats intracerebral glioma. Proc Natl Acad Sci U S A. 2013; 110:270-275. [PubMed: 23248284]

75. Roszman T, Elliott L, Brooks W. Modulation of T-cell function by gliomas. Immunol Today. 1991; 12:370-374. [PubMed: 1958290]

76. Morford LA, Elliott LH, Carlson SL, Brooks WH, Roszman TL. T cell receptor-mediated signaling is defective in T cells obtained from patients with primary intracranial tumors. Journal of immunology. 1997; 159:4415-4425.

77. Roszman TL, Brooks WH. Immunobiology of primary intracranial tumours. III. Demonstration of a qualitative lymphocyte abnormality in patients with primary brain tumours. Clinical and experimental immunology. 1980; 39:395-402. [PubMed: 6966992]

78. Wintterle S, Schreiner B, Mitsdoerffer M, Schneider D, Chen L, Meyermann R, et al. Expression of the B7-related molecule B7-H1 by glioma cells: a potential mechanism of immune paralysis. Cancer Res. 2003; 63:7462-7467. [PubMed: 14612546]

79. Fecci PE, Mitchell DA, Whitesides JF, Xie W, Friedman AH, Archer GE, et al. Increased regulatory $\mathrm{T}$-cell fraction amidst a diminished CD4 compartment explains cellular immune defects in patients with malignant glioma. Cancer Res. 2006; 66:3294-3302. [PubMed: 16540683]

80. Fontana A, Hengartner H, de Tribolet N, Weber E. Glioblastoma cells release interleukin 1 and factors inhibiting interleukin 2-mediated effects. Journal of immunology. 1984; 132:1837-1844.

81. Wrann M, Bodmer S, Demartin R, Siepl C, Hoferwarbinek R, Frei K, et al. T-Cell Suppressor Factor from Human Glioblastoma Cells Is a 12.5-Kd Protein Closely Related to Transforming Growth-Factor-Beta. Embo Journal. 1987; 6:1633-1636. [PubMed: 3497030]

82. Kuppner MC, Hamou MF, Sawamura Y, Bodmer S, de Tribolet N. Inhibition of lymphocyte function by glioblastoma-derived transforming growth factor beta 2 . Journal of neurosurgery. 1989; 71:211-217. [PubMed: 2545842]

83. Keir ME, Butte MJ, Freeman GJ, Sharpe AH. PD-1 and its ligands in tolerance and immunity. Annual review of immunology. 2008; 26:677-704.

84. Zou W, Chen L. Inhibitory B7-family molecules in the tumour microenvironment. Nat Rev Immunol. 2008; 8:467-477. [PubMed: 18500231]

85. Wilmotte R, Burkhardt K, Kindler V, Belkouch MC, Dussex G, Tribolet N, et al. B7-homolog 1 expression by human glioma: a new mechanism of immune evasion. Neuroreport. 2005; 16:10811085. [PubMed: 15973152]

86. Yao Y, Tao R, Wang XM, Wang Y, Mao Y, Zhou LF. B7-H1 is correlated with malignancy-grade gliomas but is not expressed exclusively on tumor stem-like cells. Neuro-oncology. 2009; 11:757766. [PubMed: 19264916]

87. Wei B, Wang L, Zhao X, Du C, Guo Y, Sun Z. The upregulation of programmed death 1 on peripheral blood $\mathrm{T}$ cells of glioma is correlated with disease progression. Tumour biology : the journal of the International Society for Oncodevelopmental Biology and Medicine. 2013

88. Zeng J, See AP, Phallen J, Jackson CM, Belcaid Z, Ruzevick J, et al. Anti-PD-1 blockade and stereotactic radiation produce long-term survival in mice with intracranial gliomas. International journal of radiation oncology, biology, physics. 2013; 86:343-349.

89. Hathcock K, Laszlo G, Dickler H, Bradshaw J, Linsley P, Hodes R. Identification of an alternative CTLA-4 ligand costimulatory for T cell activation. Science. 1993; 262:905-907. [PubMed: 7694361]

90. Schwartz R. Costimulation of T lymphocytes: the role of CD28, CTLA-4, and B7/BB1 in interleukin-2 production and immunotherapy. Cell. 1992; 71:1065-1068. [PubMed: 1335362] 
91. Riley JL, Mao M, Kobayashi S, Biery M, Burchard J, Cavet G, et al. Modulation of TCR-induced transcriptional profiles by ligation of CD28, ICOS, and CTLA-4 receptors. Proc Natl Acad Sci U S A. 2002; 99:11790-11795. [PubMed: 12195015]

92. Parry R, Chemnitz J, Frauwirth K, Lanfranco A, Braunstein I, Kobayashi S, et al. CTLA-4 and PD-1 receptors inhibit T-cell activation by distinct mechanisms. Mol Cell Biol. 2005; 25:95439553. [PubMed: 16227604]

93. Zheng CY, Huang DR, Liu L, Bjorkholm M, Holm G, Yi Q, et al. Cytotoxic T-lymphocyte antigen-4 microsatellite polymorphism is associated with multiple myeloma. Brit J Haematol. 2001; 112:216-218. [PubMed: 11167807]

94. Monne M, Piras G, Palmas A, Arru L, Murineddu M, Latte G, et al. Cytotoxic T-lymphocyte antigen-4 (CTLA-4) gene polymorphism and susceptibility to non-Hodgkin's lymphoma. American journal of hematology. 2004; 76:14-18. [PubMed: 15114591]

95. Erfani N, Razmkhah M, Talei AR, Pezeshki AM, Doroudchi M, Monabati A, et al. Cytotoxic T lymphocyte antigen-4 promoter variants in breast cancer. Cancer genetics and cytogenetics. 2006; 165:114-120. [PubMed: 16527605]

96. Welsh MM, Applebaum KM, Spencer SK, Perry AE, Karagas MR, Nelson HH. CTLA4 variants, UV-induced tolerance, and risk of non-melanoma skin cancer. Cancer Res. 2009; 69:6158-6163. [PubMed: 19622768]

97. Wu Q, Zhan X, Dou T, Chen H, Fan W, Zhou K, et al. CTLA4 A49G Polymorphism Shows Significant Association With Glioma Risk in a Chinese Population. Biochem Genet. 2011; 49:190-201. [PubMed: 21165767]

98. Fong B, Jin R, Wang X, Safaee M, Lisiero DN, Yang I, et al. Monitoring of regulatory T cell frequencies and expression of CTLA-4 on T cells, before and after DC vaccination, can predict survival in GBM patients. PloS one. 2012; 7:e32614. [PubMed: 22485134]

99. Fecci PE, Ochiai H, Mitchell DA, Grossi PM, Sweeney AE, Archer GE, et al. Systemic CTLA-4 blockade ameliorates glioma-induced changes to the CD4+ T cell compartment without affecting regulatory T-cell function. Clin Cancer Res. 2007; 13:2158-2167. [PubMed: 17404100]

100. Agarwalla P, Barnard Z, Fecci P, Dranoff G, Curry WT Jr. Sequential immunotherapy by vaccination with GM-CSF-expressing glioma cells and CTLA-4 blockade effectively treats established murine intracranial tumors. Journal of immunotherapy. 2012; 35:385-389. [PubMed: 22576343]

101. Hill JA, Feuerer M, Tash K, Haxhinasto S, Perez J, Melamed R, et al. Foxp3 transcription-factordependent and -independent regulation of the regulatory $\mathrm{T}$ cell transcriptional signature. Immunity. 2007; 27:786-800. [PubMed: 18024188]

102. Gavin MA, Rasmussen JP, Fontenot JD, Vasta V, Manganiello VC, Beavo JA, et al. Foxp3dependent programme of regulatory T-cell differentiation. Nature. 2007; 445:771-775. [PubMed: 17220874]

103. Wing K, Onishi Y, Prieto-Martin P, Yamaguchi T, Miyara M, Fehervari Z, et al. CTLA-4 control over Foxp3 regulatory T cell function. Science. 2008; 322:271-275. [PubMed: 18845758]

104. El Andaloussi A, Lesniak M. CD4+ CD25+ FoxP3+ T-cell infiltration and hemeoxygenase-1 expression correlate with tumor grade in human gliomas. Journal of Neurooncology. 2007:145152.

105. Heimberger AB, Abou-Ghazal M, Reina-Ortiz C, Yang DS, Sun W, Qiao W, et al. Incidence and prognostic impact of FoxP3+ regulatory T cells in human gliomas. Clin Cancer Res. 2008; 14:5166-5172. [PubMed: 18698034]

106. Vom Berg J, Vrohlings M, Haller S, Haimovici A, Kulig P, Sledzinska A, et al. Intratumoral IL-12 combined with CTLA-4 blockade elicits T cell-mediated glioma rejection. J Exp Med. 2013; 210:2803-2811. [PubMed: 24277150]

107. El Andaloussi A, Han Y, Lesniak MS. Prolongation of survival following depletion of CD4+CD25+ regulatory T cells in mice with experimental brain tumors. Journal of neurosurgery. 2006; 105:430-437. [PubMed: 16961139]

108. Poirier MD, Haban H, El Andaloussi A. A Combination of Systemic and Intracranial Anti-CD25 Immunotherapy Elicits a Long-Time Survival in Murine Model of Glioma. Journal of oncology. 2009; 2009:963037. [PubMed: 20339520] 
109. Grauer OM, Nierkens S, Bennink E, Toonen LWJ, Boon L, Wesseling P, et al. CD4 FoxP3 regulatory $\mathrm{T}$ cells gradually accumulate in gliomas during tumor growth and efficiently suppress antiglioma immune responses in vivo. Int J Cancer. 2007; 121:95-105. [PubMed: 17315190]

110. Fadul CE, Fisher JL, Gui J, Hampton TH, Cote AL, Ernstoff MS. Immune modulation effects of concomitant temozolomide and radiation therapy on peripheral blood mononuclear cells in patients with glioblastoma multiforme. Neuro-oncology. 2011; 13:393-400. [PubMed: 21339188]

111. Mitchell DA, Cui X, Schmittling RJ, Sanchez-Perez L, Snyder DJ, Congdon KL, et al. Monoclonal antibody blockade of IL-2 receptor alpha during lymphopenia selectively depletes regulatory T cells in mice and humans. Blood. 2011; 118:3003-3012. [PubMed: 21768296]

112. Maes W, Verschuere T, Van Hoylandt A, Boon L, Van Gool S. Depletion of regulatory T cells in a mouse experimental glioma model through anti-CD25 treatment results in the infiltration of non-immunosuppressive myeloid cells in the brain. Clinical \& developmental immunology. 2013; 2013:952469. [PubMed: 23710206]

113. Gedeon PC, Choi BD, Sampson JH, Bigner DD. RINDOPEPIMUT Anti-EGFRvIII Peptide Vaccine Oncolytic. Drug Future. 2013; 38:147-155.

114. Sampson JH, Schmittling RJ, Archer GE, Congdon KL, Nair SK, Reap EA, et al. A Pilot Study of IL-2R alpha Blockade during Lymphopenia Depletes Regulatory T-cells and Correlates with Enhanced Immunity in Patients with Glioblastoma. PloS one. 2012; 7

115. Paulus W, Baur I, Huettner C, Schmausser B, Roggendorf W, Schlingensiepen KH, et al. Effects of transforming growth factor-beta 1 on collagen synthesis, integrin expression, adhesion and invasion of glioma cells. Journal of neuropathology and experimental neurology. 1995; 54:236244. [PubMed: 7876891]

116. Koochekpour S, Merzak A, Pilkington GJ. Vascular endothelial growth factor production is stimulated by gangliosides and TGF-beta isoforms in human glioma cells in vitro. Cancer Lett. 1996; 102:209-215. [PubMed: 8603372]

117. Yamagiwa S, Gray JD, Hashimoto S, Horwitz DA. A role for TGF-beta in the generation and expansion of CD4+CD25+ regulatory T cells from human peripheral blood. Journal of immunology. 2001; 166:7282-7289.

118. Fantini M, Becker C, Monteleone G, Pallone F, Galle P, Neurath M. Cutting edge: TGF-beta induces a regulatory phenotype in CD4+CD25- $\mathrm{T}$ cells through Foxp3 induction and downregulation of Smad7. Journal of immunology. 2004; 172:5149-5153.

119. Liu VC, Wong LY, Jang T, Shah AH, Park I, Yang XM, et al. Tumor evasion of the immune system by converting CD4(+) CD25(-) T cells into CD4(+) CD25(+) T regulatory cells: Role of tumor-derived TGF-beta. Journal of immunology. 2007; 178:2883-2892.

120. Fontana A, Frei K, Bodmer S, Hofer E, Schreier MH, Palladino MA Jr, et al. Transforming growth factor-beta inhibits the generation of cytotoxic T cells in virus-infected mice. Journal of immunology. 1989; 143:3230-3234.

121. Kehrl JH, Wakefield LM, Roberts AB, Jakowlew S, Alvarez-Mon M, Derynck R, et al. Production of transforming growth factor beta by human $\mathrm{T}$ lymphocytes and its potential role in the regulation of T cell growth. J Exp Med. 1986; 163:1037-1050. [PubMed: 2871125]

122. Ueda R, Fujita M, Zhu X, Sasaki K, Kastenhuber ER, Kohanbash G, et al. Systemic inhibition of transforming growth factor-beta in glioma-bearing mice improves the therapeutic efficacy of glioma-associated antigen peptide vaccines. Clin Cancer Res. 2009; 15:6551-6559. [PubMed: 19861464]

123. Hulper P, Schulz-Schaeffer W, Dullin C, Hoffmann P, Harper J, Kurtzberg L, et al. Tumor localization of an anti-TGF-beta antibody and its effects on gliomas. International journal of oncology. 2011; 38:51-59. [PubMed: 21109925]

124. Stevenson JP, Kindler HL, Papasavvas E, Sun J, Jacobs-Small M, Hull J, et al. Immunological effects of the TGFbeta-blocking antibody GC1008 in malignant pleural mesothelioma patients. Oncoimmunology. 2013; 2:e26218. [PubMed: 24179709]

125. Sharpe AH. Mechanisms of costimulation. Immunological reviews. 2009; 229:5-11. [PubMed: 19426211] 
126. Ranheim EA, Kipps TJ. Activated T cells induce expression of B7/BB1 on normal or leukemic B cells through a CD40-dependent signal. J Exp Med. 1993; 177:925-935. [PubMed: 7681471]

127. Roy M, Aruffo A, Ledbetter J, Linsley P, Kehry M, Noelle R. Studies on the interdependence of gp39 and B7 expression and function during antigen-specific immune responses. European journal of immunology. 1995; 25:596-603. [PubMed: 7533092]

128. Jenkins M, Schwartz R. Antigen presentation by chemically modified splenocytes induces antigen-specific T cell unresponsiveness in vitro and in vivo. Journal of Experimental Medicine. 1987; 165:302-319. [PubMed: 3029267]

129. Nagaraj S, Gabrilovich DI. Tumor escape mechanism governed by myeloid-derived suppressor cells. Cancer Res. 2008; 68:2561-2563. [PubMed: 18413722]

130. Green JM, Noel PJ, Sperling AI, Walunas TL, Gray GS, Bluestone JA, et al. Absence of B7dependent responses in CD28-deficient mice. Immunity. 1994; 1:501-508. [PubMed: 7534617]

131. Antonia SJ, Seigne J, Diaz J, Muro-Cacho C, Extermann M, Farmelo MJ, et al. Phase I trial of a B7-1 (CD80) gene modified autologous tumor cell vaccine in combination with systemic interleukin-2 in patients with metastatic renal cell carcinoma. The Journal of urology. 2002; 167:1995-2000. [PubMed: 11956426]

132. Fishman M, Hunter TB, Soliman H, Thompson P, Dunn M, Smilee R, et al. Phase II trial of B7-1 (CD-86) transduced, cultured autologous tumor cell vaccine plus subcutaneous interleukin-2 for treatment of stage IV renal cell carcinoma. Journal of immunotherapy. 2008; 31:72-80. [PubMed: 18157014]

133. Raez LE, Cassileth PA, Schlesselman JJ, Sridhar K, Padmanabhan S, Fisher EZ, et al. Allogeneic vaccination with a B7.1 HLA-A gene-modified adenocarcinoma cell line in patients with advanced non-small-cell lung cancer. Journal of clinical oncology : official journal of the American Society of Clinical Oncology. 2004; 22:2800-2807. [PubMed: 15254047]

134. Horig H, Lee DS, Conkright W, Divito J, Hasson H, LaMare M, et al. Phase I clinical trial of a recombinant canarypoxvirus (ALVAC) vaccine expressing human carcinoembryonic antigen and the B7.1 co-stimulatory molecule. Cancer immunology, immunotherapy : CII. 2000; 49:504-514.

135. von Mehren M, Arlen P, Tsang KY, Rogatko A, Meropol N, Cooper HS, et al. Pilot study of a dual gene recombinant avipox vaccine containing both carcinoembryonic antigen (CEA) and B7.1 transgenes in patients with recurrent CEA-expressing adenocarcinomas. Clin Cancer Res. 2000; 6:2219-2228. [PubMed: 10873071]

136. Kaufman HL, Lenz HJ, Marshall J, Singh D, Garett C, Cripps C, et al. Combination chemotherapy and ALVAC-CEA/B7.1 vaccine in patients with metastatic colorectal cancer. Clin Cancer Res. 2008; 14:4843-4849. [PubMed: 18676757]

137. Mallett S, Fossum S, Barclay AN. Characterization of the MRC OX40 antigen of activated CD4 positive T lymphocytes--a molecule related to nerve growth factor receptor. The EMBO journal. 1990; 9:1063-1068. [PubMed: 2157591]

138. Paterson DJ, Jefferies WA, Green JR, Brandon MR, Corthesy P, Puklavec M, et al. Antigens of activated rat $\mathrm{T}$ lymphocytes including a molecule of 50,000 Mr detected only on CD4 positive $\mathrm{T}$ blasts. Molecular immunology. 1987; 24:1281-1290. [PubMed: 2828930]

139. Pollok KE, Kim YJ, Zhou Z, Hurtado J, Kim KK, Pickard RT, et al. Inducible T cell antigen 4-1BB. Analysis of expression and function. Journal of immunology. 1993; 150:771-781.

140. Schwarz H, Valbracht J, Tuckwell J, Vonkempis J, Lotz M. Ila, the Human 4-1bb Homolog, Is Inducible in Lymphoid and Other Cell Lineages. Blood. 1995; 85:1043-1052. [PubMed: 7849293]

141. Kjaergaard J, Tanaka J, Kim JA, Rothchild K, Weinberg A, Shu S. Therapeutic efficacy of OX-40 receptor antibody depends on tumor immunogenicity and anatomic site of tumor growth. Cancer Res. 2000; 60:5514-5521. [PubMed: 11034096]

142. Newcomb EW, Lukyanov Y, Kawashima N, Alonso-Basanta M, Wang SC, Liu M, et al. Radiotherapy enhances antitumor effect of anti-CD137 therapy in a mouse Glioma model. Radiation research. 2010; 173:426-432. [PubMed: 20334514]

143. Kuhnol C, Herbarth M, Foll J, Staege MS, Kramm C. CD137 stimulation and p38 MAPK inhibition improve reactivity in an in vitro model of glioblastoma immunotherapy. Cancer immunology, immunotherapy : CII. 2013; 62:1797-1809. 
144. Murphy KA, Lechner MG, Popescu FE, Bedi J, Decker SA, Hu P, et al. An in vivo immunotherapy screen of costimulatory molecules identifies Fc-OX40L as a potent reagent for the treatment of established murine gliomas. Clin Cancer Res. 2012; 18:4657-4668. [PubMed: 22781551]

145. Smith KE, Janelidze S, Visse E, Badn W, Salford L, Siesjo P, et al. Synergism between GM-CSF and IFN gamma: Enhanced immunotherapy in mice with glioma. International Journal of Cancer. 2007; 120:75-80.

146. Fritzell S, Sanden E, Eberstal S, Visse E, Darabi A, Siesjo P. Intratumoral temozolomide synergizes with immunotherapy in a T cell-dependent fashion. Cancer immunology, immunotherapy : CII. 2013; 62:1463-1474.

147. Park SD, Kim CH, Kim CK, Park JA, Sohn HJ, Hong YK, et al. Cross-priming by temozolomide enhances antitumor immunity of dendritic cell vaccination in murine brain tumor model. Vaccine. 2007; 25:3485-3491. [PubMed: 17275143]

148. Emens LA, Jaffee EM. Leveraging the activity of tumor vaccines with cytotoxic chemotherapy. Cancer Res. 2005; 65:8059-8064. [PubMed: 16166275]

149. O'Reilly SM, Newlands ES, Glaser MG, Brampton M, Rice-Edwards JM, Illingworth RD, et al. Temozolomide: a new oral cytotoxic chemotherapeutic agent with promising activity against primary brain tumours. European journal of cancer. 1993; 29A:940-942. [PubMed: 8499146]

150. Weinberg AD, Rivera MM, Prell R, Morris A, Ramstad T, Vetto JT, et al. Engagement of the OX-40 receptor in vivo enhances antitumor immunity. Journal of immunology. 2000; 164:2160 2169.

151. Melero I, Shuford WW, Newby SA, Aruffo A, Ledbetter JA, Hellstrom KE, et al. Monoclonal antibodies against the 4-1BB T-cell activation molecule eradicate established tumors. Nature medicine. 1997; 3:682-685.

152. Hirschhorn-Cymerman D, Rizzuto GA, Merghoub T, Cohen AD, Avogadri F, Lesokhin AM, et al. OX40 engagement and chemotherapy combination provides potent antitumor immunity with concomitant regulatory T cell apoptosis. J Exp Med. 2009; 206:1103-1116. [PubMed: 19414558]

153. Shuford WW, Klussman K, Tritchler DD, Loo DT, Chalupny J, Siadak AW, et al. 4-1BB costimulatory signals preferentially induce CD8+ T cell proliferation and lead to the amplification in vivo of cytotoxic T cell responses. J Exp Med. 1997; 186:47-55. [PubMed: 9206996]

154. Sznol M, Hodi FS, Margolin K, McDermott DF, Ernstoff MS, Kirkwood JM, et al. Phase I study of BMS-663513, a fully human anti-CD137 agonist monoclonal antibody in patients with advanced cancer. Journal of Clinical Oncology. 2008; 26

155. Nocentini G, Riccardi C. GITR: a multifaceted regulator of immunity belonging to the tumor necrosis factor receptor superfamily. European journal of immunology. 2005; 35:1016-1022. [PubMed: 15770698]

156. Cohen AD, Diab A, Perales MA, Wolchok JD, Rizzuto G, Merghoub T, et al. Agonist anti-GITR antibody enhances vaccine-induced CD8(+) T-cell responses and tumor immunity. Cancer Res. 2006; 66:4904-4912. [PubMed: 16651447]

157. Ko K, Yamazaki S, Nakamura K, Nishioka T, Hirota K, Yamaguchi T, et al. Treatment of advanced tumors with agonistic anti-GITR $\mathrm{mAb}$ and its effects on tumor-infiltrating Foxp3+CD25+CD4+ regulatory T cells. J Exp Med. 2005; 202:885-891. [PubMed: 16186187]

158. Zhou P, L'Italien L, Hodges D, Schebye XM. Pivotal roles of CD4+ effector T cells in mediating agonistic anti-GITR mAb-induced-immune activation and tumor immunity in CT26 tumors. Journal of immunology. 2007; 179:7365-7375.

159. van Lier RA, Borst J, Vroom TM, Klein H, Van Mourik P, Zeijlemaker WP, et al. Tissue distribution and biochemical and functional properties of Tp55 (CD27), a novel T cell differentiation antigen. Journal of immunology. 1987; 139:1589-1596.

160. Keller AM, Schildknecht A, Xiao Y, van den Broek M, Borst J. Expression of costimulatory ligand CD70 on steady-state dendritic cells breaks CD8+ T cell tolerance and permits effective immunity. Immunity. 2008; 29:934-946. [PubMed: 19062317] 
161. Miller J, Eisele G, Tabatabai G, Aulwurm S, von Kurthy G, Stitz L, et al. Soluble CD70: a novel immunotherapeutic agent for experimental glioblastoma. Journal of neurosurgery. 2010; 113:280-285. [PubMed: 19961309]

162. He LZ, Prostak N, Thomas LJ, Vitale L, Weidlick J, Crocker A, et al. Agonist anti-human CD27 monoclonal antibody induces $\mathrm{T}$ cell activation and tumor immunity in human CD27-transgenic mice. Journal of immunology. 2013; 191:4174-4183.

163. Schoenberger SP, Toes REM, van der Voort EIH, Offringa R, Melief CJM. T-cell help for cytotoxic T lymphocytes is mediated by CD40-CD40L interactions. Nature. 1998; 393:480-483. [PubMed: 9624005]

164. Mackey MF, Gunn JR, Ting PP, Kikutani H, Dranoff G, Noelle RJ, et al. Protective immunity induced by tumor vaccines requires interaction between CD40 and its ligand, CD154. Cancer Research. 1997; 57:2569-2574. [PubMed: 9205055]

165. Diehl L, den Boer AT, Schoenberger SP, van der Voort EI, Schumacher TN, Melief CJ, et al. CD40 activation in vivo overcomes peptide-induced peripheral cytotoxic T-lymphocyte tolerance and augments anti-tumor vaccine efficacy. Nature medicine. 1999; 5:774-779.

166. French RR, Chan HTC, Tutt AL, Glennie MJ. CD40 antibody evokes a cytotoxic T-cell response that eradicates lymphoma and bypasses T-cell help. Nature medicine. 1999; 5:548-553.

167. Li FB, Ravetch JV. Inhibitory Fc gamma Receptor Engagement Drives Adjuvant and Anti-Tumor Activities of Agonistic CD40 Antibodies. Science. 2011; 333:1030-1034. [PubMed: 21852502]

168. Zhang Y, Huang T, Hu Y, Wang Y. Activation of CD40 by soluble recombinant human CD40 ligand inhibits human glioma cells proliferation via nuclear factor-kappaB signaling pathway. Journal of Huazhong University of Science and Technology Medical sciences = Hua zhong ke ji da xue xue bao Yi xue Ying De wen ban = Huazhong keji daxue xuebao Yixue Yingdewen ban. 2012; 32:691-696.

169. Klinger M, Brandl C, Zugmaier G, Hijazi Y, Bargou RC, Topp MS, et al. Immunopharmacologic response of patients with B-lineage acute lymphoblastic leukemia to continuous infusion of $\mathrm{T}$ cell-engaging CD19/CD3-bispecific BiTE antibody blinatumomab. Blood. 2012; 119:62266233. [PubMed: 22592608]

170. Loffler A, Gruen M, Wuchter C, Schriever F, Kufer P, Dreier T, et al. Efficient elimination of chronic lymphocytic leukaemia B cells by autologous T cells with a bispecific anti-CD19/antiCD3 single-chain antibody construct. Leukemia. 2003; 17:900-909. [PubMed: 12750704]

171. Sampson JH, Choi BD, Sanchez-Perez L, Suryadevara CM, Snyder DJ, Flores CT, et al. EGFRvIII mCAR-Modified T-Cell Therapy Cures Mice with Established Intracerebral Glioma and Generates Host Immunity against Tumor-Antigen Loss. Clin Cancer Res. 2014

172. Sampson JH, Heimberger AB, Archer GE, Aldape KD, Friedman AH, Friedman HS, et al. Immunologic escape after prolonged progression-free survival with epidermal growth factor receptor variant III peptide vaccination in patients with newly diagnosed glioblastoma. Journal of clinical oncology : official journal of the American Society of Clinical Oncology. 2010; 28:4722-4729. [PubMed: 20921459]

173. Hamid O, Robert C, Daud A, Hodi FS, Hwu WJ, Kefford R, et al. Safety and tumor responses with lambrolizumab (anti-PD-1) in melanoma. The New England journal of medicine. 2013; 369:134-144. [PubMed: 23724846]

174. Wolchok JD, Kluger H, Callahan MK, Postow MA, Rizvi NA, Lesokhin AM, et al. Nivolumab plus ipilimumab in advanced melanoma. The New England journal of medicine. 2013; 369:122133. [PubMed: 23724867]

175. Riley JL. Combination checkpoint blockade--taking melanoma immunotherapy to the next level. The New England journal of medicine. 2013; 369:187-189. [PubMed: 23724866] 


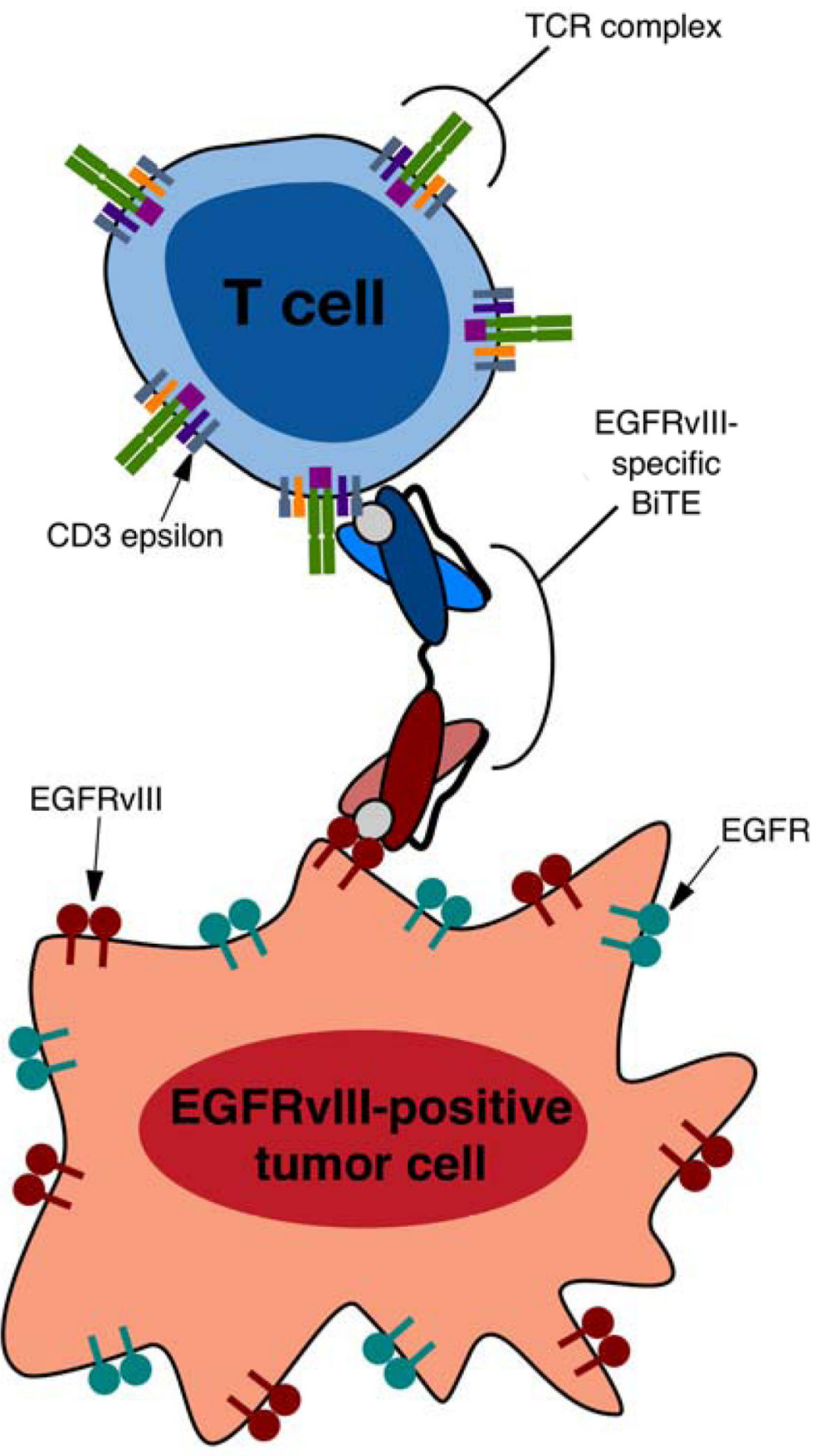

Figure 1.

A schematic representing EGFRvIII-specific BiTE creating an immunologic synapse by binding to a tumor cell via the tumor specific antigen EGFRvIII and a T cell via CD3epsilon. Note that the EGFRvIII binding portion does not bind to the wild-type EGFR, thus mediating tumor cell specific targeting. 

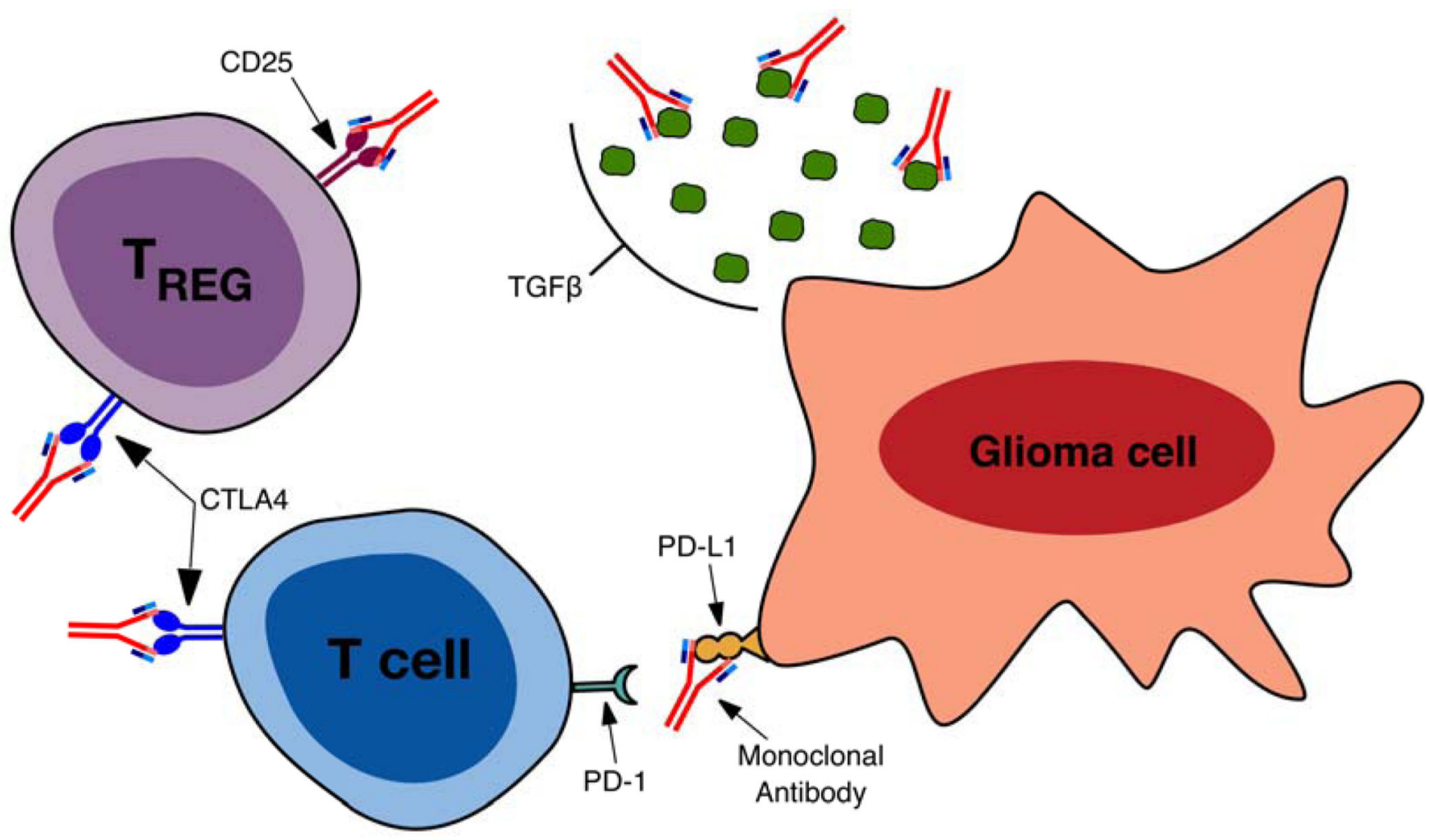

Figure 2.

A depiction of strategies under clinical investigation to enhance immune mediated tumor cell rejection via mAb mediated blockade of immunosuppressive signals. CTLA-4 blockade inhibits signaling via the receptor, blocking the induction of effector $\mathrm{T}$ cell tolerance to tumor antigens and reducing the immunosuppressive function of $\mathrm{T}_{\text {Regs. }}$ CD25 blockade inhibits the development of the $\mathrm{T}_{\mathrm{Reg}}$ linage, resulting in a reduction in the maintenance and survival of $\mathrm{T}^{\text {Regs. }} \mathrm{mAb}$ binding to TGF- $\beta$ reduces the level of extracellular protein available to act on receptors, diminishing TGF- $\beta$ induced tumor cell migration and angiogenesis, inhibition of cytotoxic T lymphocyte (CTL) generation and the generation of a $\mathrm{T}_{\mathrm{Reg}}$ phenotype in naïve $\mathrm{CD} 4^{+} \mathrm{T}$ cells. Blockade of interaction of PD- 1 with its ligand increases $\mathrm{T}$ cell receptor (TCR) signaling, up-regulates expression of pro-inflammatory cytokines and reduces $\mathrm{T}$ cell apoptosis. 


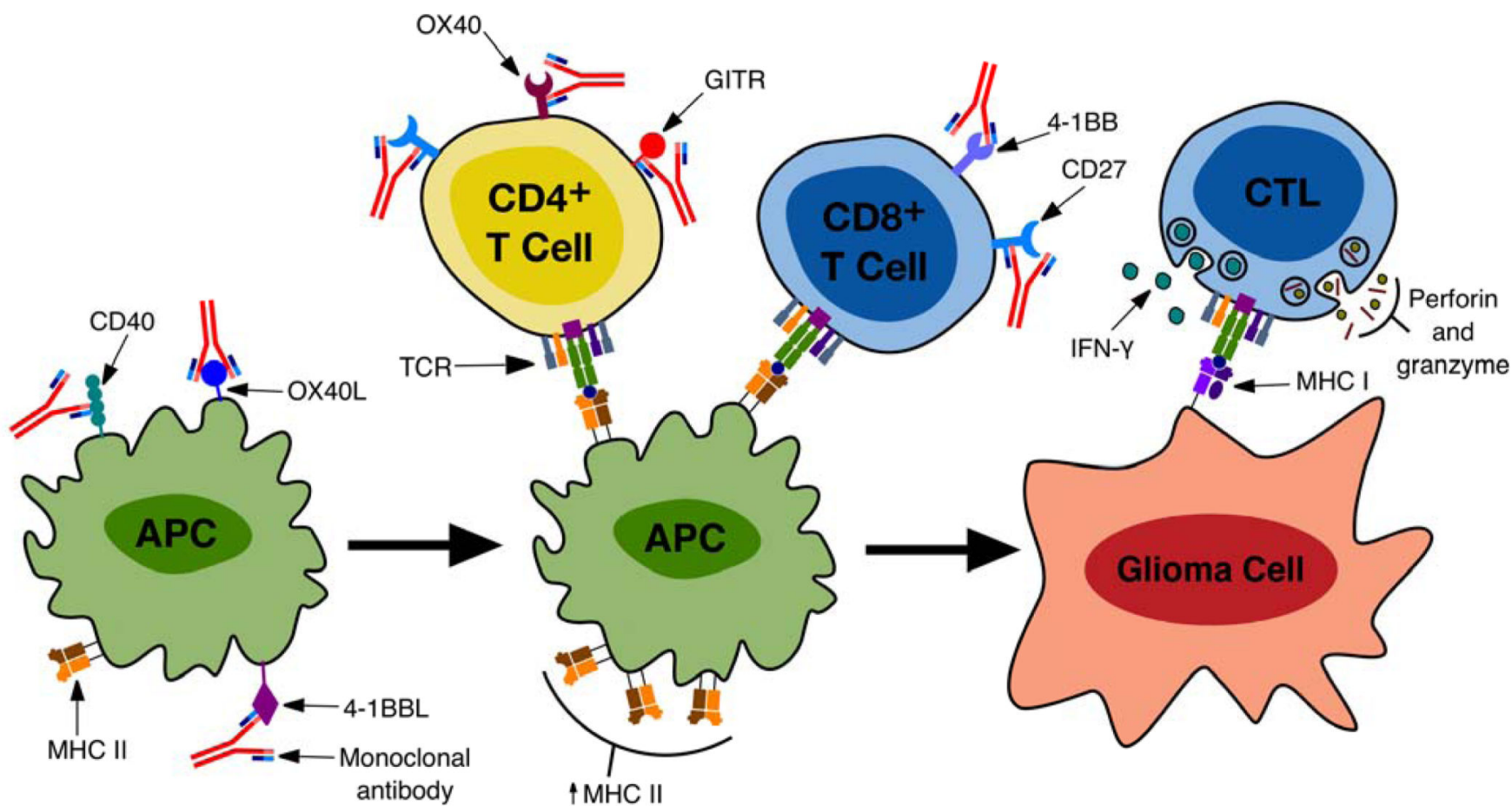

Figure 3.

A summary of stages of the immune response against tumor cells where mAbs can be used to enhance glioma cell specific lysis. mAbs agonistic for CD40, OX40L and 4-1BBL present on antigen presenting cells (APCs) result in an increase in pro-inflammatory cytokine production and MHC expression on APCs. CD27 stimulation enhances proliferation and survival of effector and memory T cells, increases IL-2 production and increases the secretion of effector cytokines. mAb mediated stimulation of OX40 results in clonal expansion and survival of effector $\mathrm{T}$ cells, activation and survival of memory $\mathrm{T}$ cells, blocks the activity of $T_{\text {Regs }}$ and antagonizes the generation of inducible $T_{\text {Regs }}$. $m A b s$ agonistic for 4-1BB enhance the survival of activated and memory $\mathrm{T}$ cells, maintain effector function during prolonged antigen stimulation and increase tumoricidal activity. mAbs agonistic for GITR likewise increase the tumoricidal immune response. These pathways converge with the generation of cytotoxic T lymphocytes (CTLs) which upon interaction with glioma cells mediate tumor cell lysis via the release of interferon-gamma (IFN $\gamma$ ) and perforin and granzyme. 